\title{
Prolonged polyarthralgia in a German traveller with Mayaro virus infection without inflammatory correlates
}

\author{
${\text { Christian Theilacker }{ }^{1 *} \text {, Jürgen Held }{ }^{2} \text {, Ludger Allering }}^{3}$, Petra Emmerich³ ${ }^{3}$ Jonas Schmidt-Chanasit ${ }^{3}$, \\ Winfried V Kern ${ }^{1}$ and Marcus Panning ${ }^{4}$
}

\begin{abstract}
Background: Mayaro virus is endemic in South America and sporadic outbreaks have been described. It causes a dengue-like febrile illness accompanied by severe and long-lasting polyarthralgias. Outside endemic regions, however, the disease is not well known and can be misdiagnosed as dengue. International travellers are at risk to acquire Mayaro virus and due to increased worldwide travel infectious disease specialists need to be aware of such rare clinical entities.

Case presentation: We report the first Mayaro virus infection imported into Germany. A 20-year-old woman developed fever, myalgia, maculopapular rash, and polyarthralgias following a 10-day trip in the Rurrenabaque region of Bolivia. Severe polyarthralgias persisted for 5 months and were treated with non-steroidal anti-inflammatory drugs. Serological analysis demonstrated Mayaro virus-specific-lgM and -lgG antibodies two months after onset of symptoms. Except for CXCL8/IL-8 other proinflammatory chemokines and cytokines were unremarkable at this time.

Conclusions: Dissemination of knowledge on rare disease might improve patient management. Understanding the inherent features of Mayaro virus infection and how the virus interacts with its host are essential for optimal patient care and therapy.
\end{abstract}

Keywords: Mayaro virus, Alphavirus, Persistent arthralgia, Inflammatory cytokines

\section{Background}

Mosquito-borne alphaviruses belong to the family Togaviridae and have a worldwide distribution. They can be associated with rheumatic disease in humans. The most important arthritogenic alphaviruses are Barmah Forest virus (BFV), chikungunya virus (CHIKV), Ross River virus (RRV), Sindbis virus (SINV), and Mayaro virus (MAYV). Occasionally, these arthritogenic alphaviruses can cause large and unpredictable outbreaks as seen in the 2004-2011 CHIKV epidemic in the Indian Ocean [1]. Geographic range expansion of alphaviruses and increased worldwide travel are of emerging public health concern $[2,3]$. Of note, importation of alphaviruses into non-endemic regions can delay proper treatment as

\footnotetext{
* Correspondence: christian.theilacker@uniklinik-freiburg.de 'Universitätsklinik Freiburg i.Br, Medizinische Klinik II / Sektion Klinische Infektiologie, Hugstetter Str. 55, 79106 Freiburg i.Br, Germany Full list of author information is available at the end of the article
}

doctors are not familiar with the diseases and reliable diagnostic methods are lacking at large [3,4]. Disease in humans is usually self-limiting, but polyarthralgia can be debilitating and long-lasting. This prominent feature has been reported in particular in cases of CHIKV and MAYV infection. However, little is known about the underlying mechanism of polyarthralgia. It has been postulated that the inflammatory immune response can contribute to the pathology [5]. Here, we describe the first MAYV case imported into Germany and present data on the inflammatory immune response during the polyarthralgic stages of the disease.

\section{Case presentation}

In July 2012, a 20-year old woman presented to our outpatient clinic with symmetrical polyarthritis after a longterm travel to South America. At presentation, she complained about highly painful ankles and elbows, and she was barely able to walk without assistance. Between September 2011 and June 2012 she had travelled as a

\section{Biomed Central}


tourist through Peru, Bolivia, and Ecuador. In Mid-April 2012 she spent 10 days in the tropical rainforest of the Rurrenabaque region, which is situated in the Amazon basin about $400 \mathrm{~km}$ north of La Paz, Bolivia. There, she volunteered in a wildlife resort, taking care of a variety of monkeys and wild cats. One day after leaving the resort she developed spiking fevers, headache, myalgia followed by aphthous oral ulcers and a maculopapular rash of the whole body four days later. Around the same time she developed a diffuse arthralgia, which after initial improvement slowly worsened and became highly incapacitating. Her previous medical history was unremarkable. She did not take regular medication. Prior to her travel, she had received complete vaccinations for yellow fever, rabies, hepatitis A and B.

On physical examination tenderness and mild swelling of both ankles was noted. Tenderness of the elbows, shoulders and interphalangeal joints and wrists without swelling was also observed.

Results of a full blood count, liver and renal function tests were normal, as were levels of electrolytes, lactate dehydrogenase, and C-reactive protein. Blood cultures remained sterile. Blood smears for malaria were repeatedly negative. Serologic testing for cytomegalovirus, hepatitis $\mathrm{C}$ virus, human immunodeficiency virus, Borrelia burgdorferi, and Treponema pallidum were negative. Serology for Epstein-Barr virus and parvovirus B19 was indicative of past infection. A slightly raised dengue virus (DENV) IgG was interpreted as cross-reactivity after yellow fever vaccination while DENV IgM was negative. In addition, autoimmune serology including anti-citrullin peptide antibodies or anti-nuclear antibodies was negative.

Due to her travel to the Amazon basin and prolonged course of arthralgia, MAYV infection was considered as a differential diagnosis. Serologic testing for mosquito- borne alphaviruses using the indirect immunofluorescence test (IIFT) and virus neutralization test (VNT) confirmed the diagnosis of MAYV infection (Table 1). Testing for MAYV RNA was not performed, since the time of presentation was more than 2 months after disease manifestation.

Serum samples collected 83, 106, and 167 days after onset of symptoms, respectively, were analyzed for chemokine/cytokine levels using the Cytometric Bead Array (CBA) Human Chemokine Kit and Human Th1/Th2 Cytokine kit (Becton Dickenson, Heidelberg, Germany) according to the manufacturer's instructions.

Except for CXCL8/IL-8, which was elevated more than 15 -fold on day 83 after onset of symptoms, chemokines (CCL5/RANTES, CXCL9/MIG, CCL2/MCP-1, and CXCL10/IP-10) and cytokines (IL-2, IL-4, IL-5, IL-10, TNF- $\alpha$, and IFN- $\gamma$ ) were not different to healthy controls $(\mathrm{n}=5$ samples) (Table 2).

The patient was treated symptomatically with non-steroidal anti-inflammatory drugs (NSAID). During follow up visits the patient reported persistent arthalgias of both ankles and elbows, which slowly improved over time. The patient continued to take NSAID for over 2 months and her symptoms finally resolved after 5 months.

\section{Discussion}

To our knowledge, this MAYV case is the fourth of a European patient with a travel history to South America and in particular the first imported MAYV case into Germany $[4,6,7]$. MAYV infection is still rare in travellers and consultation of infectious disease specialists is instrumental in making the correct diagnosis [4].

Our patient presented with a travel and exposure history typical for an infection with an arthritogenic alphavirus and displayed symptoms identical to reports published

Table 1 Serological testing for alphaviruses

\begin{tabular}{|c|c|c|c|c|c|c|}
\hline \multirow[b]{3}{*}{ Virus } & \multicolumn{4}{|c|}{ Indirect immunofluorescence assay } & \multicolumn{2}{|c|}{ Virus neutralization assay } \\
\hline & \multicolumn{2}{|c|}{ First serum sample* } & \multicolumn{2}{|c|}{ Second serum sample ${ }^{* *}$} & \multirow[t]{2}{*}{ First serum sample* } & \multirow[t]{2}{*}{ Second serum sample** } \\
\hline & $\lg M$ & IgG & $\lg M$ & IgG & & \\
\hline Mayaro virus (MAYV) & 1:10240 & $1: 160$ & $1: 20480$ & $1: 160$ & 1:80 & $1: 160$ \\
\hline Semliki forest virus (SFV) & $1: 20$ & $<1: 20$ & $1: 40$ & $<1: 20$ & 1:40 & $1: 40$ \\
\hline O'nyong-nyong (ONNV) & $1: 20$ & $<1: 20$ & $1: 40$ & $<1: 20$ & $<1: 20$ & $<1: 20$ \\
\hline Chikungunya virus (CHIKV) & $1: 20$ & $<1: 20$ & $1: 40$ & $<1: 20$ & $<1: 20$ & $<1: 20$ \\
\hline Ross river virus(RRV) & $1: 20$ & $<1: 20$ & $1: 20$ & $<1: 20$ & $<1: 20$ & $<1: 20$ \\
\hline Barmah forest virus (BHV) & $1: 20$ & $<1: 20$ & $1: 20$ & $<1: 20$ & $<1: 20$ & $<1: 20$ \\
\hline Sindbis virus (SINV) & $1: 20$ & $<1: 20$ & $1: 20$ & $<1: 20$ & $<1: 20$ & $<1: 20$ \\
\hline Western equine encephalitis virus (WEEV) & $1: 20$ & $<1: 20$ & $1: 20$ & $<1: 20$ & $<1: 20$ & $<1: 20$ \\
\hline Eastern equine encephalitis virus(EEEV) & $1: 20$ & $<1: 20$ & $1: 20$ & $<1: 20$ & $<1: 20$ & $<1: 20$ \\
\hline Venezuelan equine encephalitis virus (VEEV) & $1: 20$ & $<1: 20$ & $1: 20$ & $<1: 20$ & $<1: 20$ & $<1: 20$ \\
\hline
\end{tabular}

*Serum sample day 83 after onset of symptoms.

**Serum sample day 106 after onset of symptoms.

Antibody titers were measured by indirect immunofluorescence test and virus neutralization test. Shown are results on day 83 and 106 after onset of symptoms, respectively. 
Table 2 Analysis of cytokine/chemokine levels

\begin{tabular}{lrrrr}
\hline & \multicolumn{4}{c}{ Cytokine/chemokine level in pg/ml } \\
\cline { 2 - 5 } Cytokine/chemokine & $\begin{array}{c}\text { Serum } \\
\text { day } \mathbf{8 3}\end{array}$ & $\begin{array}{c}\text { Serum } \\
\text { day } \mathbf{1 0 6}\end{array}$ & $\begin{array}{c}\text { Serum } \\
\text { day } \mathbf{1 6 7}\end{array}$ & $\begin{array}{r}\text { Control } \\
\text { (mean) }\end{array}$ \\
\hline CXCL8/IL-8 & 45,9 & 4,1 & 2,7 & 2,9 \\
CCL5/RANTES & 10277 & 10218 & 6958 & 10005 \\
CXCL9/MIG & 46 & 31,6 & 20,1 & 22,8 \\
CCL2/MCP-1 & 70,1 & 80,9 & 85,6 & 66,1 \\
CXCL10/IP-10 & 129,6 & 77,2 & 61,4 & 43,3 \\
IL-2 & 0 & 0,1 & 0,9 & 0,01 \\
IL-4 & 0 & 0 & 0 & 0 \\
IL-5 & 0,2 & 0,3 & 0,5 & 0,1 \\
IL10 & 0,8 & 0,5 & 0,9 & 0,8 \\
TNF- $a$ & 0 & 0 & 0 & 0 \\
IFN- - & 0 & 0,5 & 0 & 0 \\
\hline Cytoknyyyyy
\end{tabular}

Cytokine and chemokine response as measured on three consecutive dates within the chronic stage of MAYV disease. The control represents the mean of 5 individual determinations of 5 healthy volunteers.

previously [4,6,7]. However, knowledge about exotic alphaviruses is rather limited among general practitioners and MAYV infection might frequently be misdiagnosed as dengue on clinical grounds. In our case serologic results rapidly confirmed the clinical diagnosis supporting the importance of specific laboratory tests. It should be noted, however, that diagnostic tests for exotic alphaviruses are not widely available hampering the diagnosis in routine practice.

VNT is considered gold standard for the diagnosis of MAYV infection. However, the requirement for a biosafety level 3 laboratory to conduct these assays considerably limits their utility. IIFT and ELISA have been also described, but they are prone to cross-reactivity between alphaviruses $[4,6]$. Diagnosis in our case was unambiguous and no significant cross-reaction with related alphaviruses was observed. Interestingly, MAYV IgM antibodies were detectable for at least 3,5 months. It remains speculative if persisting IgM can serve as a diagnostic indicator of severe disease and arthritis $[8,9]$.

Beyond pure case detection it should be noted that travellers can potentially act as sentinel for emerging infectious diseases [10]. In light of the spread of competent vectors for mosquito-borne diseases in Europe and elsewhere, surveillance of vector-borne diseases is of major public health importance. Therefore, the dissemination of reliable diagnostic methods is an important prerequisite both for individual and public health as experienced with other emerging infections, e.g. CHIKV and west nile virus $[3,11]$.

Among the arthritogenic alphaviruses MAYV is restricted to South America and infections have been reported from countries including Brazil, Bolivia, Colombia, the Guiana's, and Venezuela. Sporadic outbreaks involving up to 100 cases have been described in several regions [12-14]. Resident forrest workers and hunters are at highest risk to acquire MAYV infection [4,6,7]. In South America, MAYV is responsible for about $1 \%$ of arbovirusassociated febrile illness [15]. The virus is transmitted by bites of Haemagogus janthinomys which lives in the forest canopy and propagates in a sylvatic cycle predominantly in monkeys $[16,17]$. Hence, working and living in the Amazon rain forest is the most important risk factor for the acquisition of MAYV infection [12,13,18]. Clearly, our patient was at risk while working in a wildlife resort. Recently, however, also cases of urban transmission of MAYV infection have been described [19].

From a clinical perspective arthritogenic alphaviruses cause a similar picture consisting of acute fever, malaise, headache, maculo-papular rash, myalgia lasting for 3 - 7 days, and a characteristic and often debilitating polyarthraglia/polyarthritis lasting up to 6 months [20]. A rash is found in $20-60 \%$ of patients $[14,19,21]$ In a classical fashion our patient reportedly suffered from these cardinal symptoms during the acute phase of infection. Viraemia is short-lived and controlled by the innate immune system as well as the appearance of antibodies after 5-7 days. The hallmark of all arthritogenic alphaviruses are sometimes long-lasting polyarthralgias and/or polyarthritis. There is evidence that virus induced inflammation is responsible for these arthropathies [20]. To the best of our knowledge no reports on the inflammatory cytokine response in MAYV infection are available to date. Supporting the findings of Chow et al., who analyzed patients with persistent arthralgia induced by CHIKV infection, the Th1/Th2 response remained below the limit of detection at all time points in our patient. A slightly elevated IL-8 concentration could be interpreted as waning levels after acute infection [5]. Interestingly, Chow et al. could show that levels of IL-6 and granulocyte macrophage colonystimulating factor were associated with persistent arthralgias. Further studies on MAYV are needed, as both markers were not included in our panel. Although TNF- $\alpha$ and INF- $\gamma$ are involved in chronic inflammatory diseases such as rheumatic arthritis and were detected in a number of arthritogenic alphavirus infections we did not detect increased levels in our patient. Differences in genetic background, disease severity or the etiologic agent may account for this finding and require further studies. Beyond the analysis of cytokines/chemokines in serum the analysis of gene expression profiles of these immune mediators may shed more light on the immune response in MAYV infection.

\section{Conclusions}

Here, we report the first case of MAYV associated arthritis in a returning traveller from Germany. No inflammatory correlate was detectable despite long term 
sequelae. With increasing intercontinental travel, infectious disease specialists and rheumatologists need to be aware of alphavirus infection as a cause of febrile illness followed by persisting polyathralgia. Our clinical case illustrates that MAYV infection should be considered after travel to tropical South America, especially, if the travel itinerary included extended exposure in the Amazon rain forest and its wildlife.

\section{Consent}

Written informed consent was obtained from the patient for publication of this case. A copy of the written consent is available for review by the Series Editor of this journal.

\section{Competing interests}

The authors declare that they have no competing interests.

\section{Authors' contributions}

CT and MP drafted and wrote the manuscript. CT and WVK took care of the patient. JH and MP carried out the cytokine assays. LA, PE, and JSC carried out the IIFT and VNT. WVK critically revised the manuscript. All authors have read the manuscript and approved its final version.

\section{Acknowledgements}

The authors would like to acknowledge Sabine Köhler and Marcus GraeberGerberding for technical assistance.

\section{Author details}

'Universitätsklinik Freiburg i.Br, Medizinische Klinik II / Sektion Klinische Infektiologie, Hugstetter Str. 55, 79106 Freiburg i.Br, Germany.

${ }^{2} U$ niversitätsklinik Freiburg i.Br, Department f. Medizinische Mikrobiologie und Hygiene, Institut f. Medizinische Mikrobiologie, Hermann-Herder-Str. 11, 79104 Freiburg. ${ }^{3}$ Bernhard-Nocht-Institut f. Tropenmedizin, Bernhard-Nocht-Str 74, 20359 Hamburg, Germany. ${ }^{4}$ Universitätsklinik Freiburg i.Br, Department f. Medizinische Mikrobiologie und Hygiene, Institut f. Virologie,

Hermann-Herder-Str. 11, 79104 Freiburg.

Received: 31 May 2013 Accepted: 6 August 2013

Published: 8 August 2013

\section{References}

1. Schuffenecker I, Iteman I, Michault A, Murri S, Frangeul L, Vaney M-C, Lavenir R, Pardigon N, Reynes J-M, Pettinelli F, Biscornet L, Diancourt L, Michel S, Duquerroy S, Guigon G, Frenkiel M-P, Bréhin A-C, Cubito N, Desprès P, Kunst F, Rey FA, Zeller H, Brisse S: Genome microevolution of chikungunya viruses causing the Indian Ocean outbreak. PLOS Med 2006, 3:e263.

2. Charrel RN, De Lamballerie X, Raoult D: Chikungunya outbreaks-the globalization of vectorborne diseases. N Engl J Med 2007, 356:769-771.

3. Rezza G, Nicoletti L, Angelini R, Romi R, Finarelli AC, Panning M, Cordioli $P$, Fortuna C, Boros S, Magurano F, Silvi G, Angelini P, Dottori M, Ciufolini MG, Majori GC, Cassone A, CHIKV study group: nfection with chikungunya virus in Italy: an outbreak in a temperate region. Lancet 2007, 370:1840-1846.

4. Neumayr A, Gabriel M, Fritz J, Günther S, Hatz C, Schmidt-Chanasit J, Blum J: Mayaro virus infection in traveler returning from Amazon Basin, northern Peru. Emerg Infect Dis 2012, 18:695-696.

5. Chow A, Her Z, Ong EKS, Chen J-M, Dimatatac F, Kwek DJC, Barkham T, Yang H, Rénia L, Leo Y-S, Ng LFP: Persistent arthralgia induced by Chikungunya virus infection is associated with interleukin- 6 and granulocyte macrophage colony-stimulating factor. J Infect Dis 2011, 203:149-157.

6. Hassing R-J, Leparc-Goffart I, Blank SN, Thevarayan S, Tolou H, Van Doornum G, Van Genderen PJ: Imported Mayaro virus infection in the Netherlands. $J$ Infect 2010, 61:343-345.

7. Receveur MC, Grandadam M, Pistone T, Malvy D: Infection with Mayaro virus in a French traveller returning from the Amazon region, Brazil, January, 2010. Euro Surveill 2010, 15(18):19563.

8. Malvy D, Ezzedine K, Mamani-Matsuda M, Autran B, Tolou H, Receveur M-C, Pistone T, Rambert J, Moynet D, Mossalayi D: Destructive arthritis in a patient with chikungunya virus infection with persistent specific IgM antibodies. BMC Infect Dis 2009, 9:200

9. Chopra A, Anuradha V, Ghorpade R, Saluja M: Acute Chikungunya and persistent musculoskeletal pain following the 2006 Indian epidemic: a 2-year prospective rural community study. Epidemiol Infect 2012, 140:842-850.

10. Gautret P, Cramer JP, Field V, Caumes E, Jensenius M, Gkrania-Klotsas E, De Vries PJ, Grobusch MP, Lopez-Velez R, Castelli F, Schlagenhauf P, Hervius Askling H, Von Sonnenburg F, Lalloo DG, Loutan L, Rapp C, Basto F, Santos O'Connor F, Weld L, Parola P, EuroTravNet Network: Infectious diseases among travellers and migrants in Europe, EuroTravNet 2010. Euro Surveill 2012, 17(26):20205.

11. Sambri V, Capobianchi M, Charrel R, Fyodorova M, Gaibani P, Gould E, Niedrig M, Papa A, Pierro A, Rossini G, Varani S, Vocale C, Landini MP: West Nile virus in Europe: emergence, epidemiology, diagnosis, treatment, and prevention. Clin Microbiol Infect 2013, 19(8):699-704. doi:10.1111/1469-0691.12211.

12. Izurieta RO, Macaluso M, Watts DM, Tesh RB, Guerra B, Cruz LM, Galwankar S, Vermund SH: Hunting in the Rainforest and Mayaro Virus Infection: An emerging Alphavirus in Ecuador. J Glob Infect Dis 2011, 3:317-323.

13. Azevedo RSS, Silva EVP, Carvalho VL, Rodrigues SG, Nunes-Neto JP, Monteiro $H$, Peixoto VS, Chiang JO, Nunes MRT, Vasconcelos PFC: Mayaro fever virus, Brazilian Amazon. Emerg Infect Dis 2009, 15:1830-1832.

14. Pinheiro FP, Freitas RB, Travassos da Rosa JF, Gabbay YB, Mello WA, LeDuc JW: An outbreak of Mayaro virus disease in Belterra, Brazil. I. Clinical and virological findings. Am J Trop Med Hyg 1981, 30:674-681.

15. Forshey BM, Guevara C, Laguna-Torres VA, Cespedes M, Vargas J, Gianella A, Vallejo E, Madrid C, Aguayo N, Gotuzzo E, Suarez V, Morales AM, Beingolea L, Reyes N, Perez J, Negrete M, Rocha C, Morrison AC, Russell KL, Blair PJ, Olson JG, Kochel TJ, NMRCD Febrile Surveillance Working Group: Arboviral etiologies of acute febrile illnesses in Western South America, 2000-2007. PLoS Negl Trop Dis 2010, 4:e787.

16. De Thoisy B, Gardon J, Salas RA, Morvan J, Kazanji M: Mayaro virus in wild mammals, French Guiana. Emerg Infect Dis 2003, 9:1326-1329.

17. Hoch AL, Peterson NE, LeDuc JW, Pinheiro FP: An outbreak of Mayaro virus disease in Belterra, Brazil. III. Entomological and ecological studies. Am J Trop Med Hyg 1981, 30:689-698.

18. Batista PM, Andreotti R, Chiang JO, Ferreira MS, Vasconcelos PFDC: Seroepidemiological monitoring in sentinel animals and vectors as part of arbovirus surveillance in the state of Mato Grosso do Sul, Brazil. Rev Soc Bras Med Trop 2012, 45:168-173.

19. Mourão MPG, Bastos MS, De Figueiredo RP, Gimaque JBL, Dos Santos Galusso E, Kramer VM, De Oliveira CMC, Naveca FG, Figueiredo LTM: Mayaro fever in the city of Manaus, Brazil, 2007-2008. Vector Borne Zoonotic Dis 2012, 12:42-46.

20. Suhrbier A, Jaffar-Bandjee M-C, Gasque P: Arthritogenic alphaviruses-an overview. Nat Rev Rheumatol 2012, 8:420-429.

21. Tesh RB, Watts DM, Russell KL, Damodaran C, Calampa C, Cabezas C, Ramirez G, Vasquez B, Hayes CG, Rossi CA, Powers AM, Hice CL, Chandler L, Cropp BC, Karabatsos N, Roehrig JT, Gubler DJ: Mayaro virus disease: an emerging mosquito-borne zoonosis in tropical South America. Clin Infect Dis 1999, 28:67-73.

doi:10.1186/1471-2334-13-369

Cite this article as: Theilacker et al:: Prolonged polyarthralgia in a German traveller with Mayaro virus infection without inflammatory correlates. BMC Infectious Diseases 2013 13:369.

\section{Submit your next manuscript to BioMed Central and take full advantage of:}

- Convenient online submission

- Thorough peer review

- No space constraints or color figure charges

- Immediate publication on acceptance

- Inclusion in PubMed, CAS, Scopus and Google Scholar

- Research which is freely available for redistribution 